\title{
Alejandro R. Isla (1944-2019)
}

El Comité Editorial de Estudios Atacameños quiere dedicar este número 60 a la memoria de Alejandro Isla. Alejandro colaboró durante dieciséis años con nosotros, integrando el claustro de profesores del Postgrado en Antropología, primero Maestría y luego Doctorado, dictado en el Instituto de Arqueología y Antropología (IAA) de la Universidad Católica del Norte, conjuntamente con la Universidad de Tarapacá. Asimismo, sus contribuciones en antropología política y estudios andinos han estimulado e influido a generaciones de alumnos y colegas.

\section{Dra. Marina Weinberg \\ Editora General \\ Estudios Atacameños.}

Arqueología y Antropología Surandinas 